\title{
Identification of Polymorphism and Association Analyses of FMO3 Gene Related With Carcass and Meat Quality in Cihateup Duck
}

\author{
Anggraeni $^{1,2}$, Asep Gunawan ${ }^{3}$, Rukmiasih $^{3}$, Tuti Suryati ${ }^{3}$, Cece Sumantri ${ }^{3 *}$. \\ ${ }^{1}$ Graduate School of Animal Science, Faculty of Animal Science,Bogor Agricultural University, Indonesia \\ ${ }^{2}$ Department of Animal Husbandry, Faculty ofAgriculture ,University of Djuanda, Indonesia \\ ${ }^{3}$ Department of Animal Production and Technology, Faculty of Animal Sciences, BogorAgricultural University Indonesia \\ *Corresponding author: csumantri12@gmail.com
}

\begin{abstract}
The aim of this study was to identify the association polymorphisme of the $\mathrm{FMO}$ gene related to carcass and meat quality in Indonesian Cihateup ducks. A total of 76 Indonesian Cihateup ducks were used in this study. Tissues from breast muscle were used for genomic DNA. Association analysis showed that the SNP g.849A $>\mathrm{G}$ was highly significantly associated $(\mathrm{P}<0.01)$ with live weight $(\mathrm{LW})$, carcass weight $(\mathrm{CW})$, breast muscle weight (BMW), $\mathrm{pH}$, cooking loss, drip loss (DL), lightness $\left(\mathrm{L}^{*}\right)$ and redness ( $\left.\mathrm{a}^{*}\right)$, TBARS and TMA. Compared to the GG genotype, the AG genotype exhibited greater levels $(P<0.05) L W, C W, p H, a^{*}$, TBARS and TMA but not DL and $\mathrm{L}^{*}$. These results will improve the understanding of the functions of the $\mathrm{FMO3}$ gene in carcass and meat quality within the liver and will shed light on FMO3 as a candidate gene in the selection of ducks with good carcass and meat quality traits

Keywords: FMO3gene, PCR-RFLP, carcass and meat quality, Indonesian duck
\end{abstract}

Abstrak.Tujuan dari penelitian ini untuk mengidentifikasi asosiasi dan ekspresi dari gen FMO3 terhadap sifat karkas dan kualitas daging pada Itik Cihateup. Total itik yang digunakan pada penelitian ini berjumlah 76 ekor. Jaringan otot dada dan hati digunakan masing-masing untuk analisis genomik DNA. Hasil asosiasi menunjukkan gen $\mathrm{FMO3}$ pada titik mutasi SNP g.849A $>\mathrm{G}$ menunjukkan secara signifikan $(\mathrm{P}<0.01)$ berhubungan dengan bobot hidup (LW), berat karkas (CW), berat otot dada (BMW), pH, susut masak, drip loss, kecerahan daging $\left(L^{*}\right)$, tingkat warna merah $\left(a^{*}\right)$, TBARS dan TMA. Apabila dibandingkan dengan genotip GG, genotip AG memiliki bobot komponen karkas dan kualitas daging lebih besar dalam hal LW, CW, pH, a*, TBARS dan TMA namun lebih kecil untuk nilai drip loss dan $L^{*}$. Hasil studi ini memperjelas tentang mekanisme dan fungsi dan peran gen FMO3 terhadap sifat karkas dan kualitas daging itik serta peranannya FMO3 untuk dapat digunakan sebagai kandidat gen dalam memilih sifat karkas dan kualitas daging itik yang baik.

Kata kunci: Gen FMO3, PCR RFLP, sifat karkas, kualitas daging, itik cihateup

\section{Introduction}

Carcass and meat quality traits are economically important traits in duck. The ability to genetically select for animals that better suit a consumer's needs in terms of the amount of meat quality that can be predicted would benefit the farmers. Carcass and meat quality traits are important in animal breeding programs, and include live weight (LW), carcass weight $(\mathrm{CW}), \mathrm{pH}$, meat color $(\mathrm{MC})$, drip loss (DL), and other traits. However, these traits are difficult to improve using conventional selection (Boukha et al. 2011). Moreover, their measurement is both expensive and difficult, and can only be conducted after slaughtered. Selection on the basis molecular genetic such as variant analysis single nucleotide polymorphism
(SNPs) of candidate gene approach has been already successfully applied to investigate several DNA markers (van der Steen et al. 2005). Identification of SNPs within genes influencing meat quality traits and their association and gene expression is the important and generally applied tools to characterize candidate genes. Therefore, it is very necessary to study the related gene mechanism regulating in carcass and meat quality in meat ducks.

One of the candidate genes that propose an important role in regulating in carcass and meat quality is flavin monooxygenase family member 3 (FMO3). The FMO family of enzymes converts lipophilic compounds into more polar metabolites and decreases the activity of these 
compounds (Cashman, 2005). The FMO3 enzyme is the predominant enzyme in the adult human liver involved in the degradation of trimethylamine (TMA). FMO3 was reported to be downregulated in tissues with higher fat deposition and it could be speculated that the higher fat deposition may be caused by diminished $\mathrm{FMO} 3$ and related with fatty acid oxidation or increased adipogenesis of adipocytes in muscle (Wang et al. 2013).

Numerous studies have shown that FMO3 and other family of FMO gene plays an important role in regulating fishy off-flavor and taint pigs, cows, and chickens (Gunawan et al. 2013; Gleen et al., 2007; Mo et al. 2013; Honkatukia et al., 2005;), which are important references in the study of duck meat quality metabolism. Glenn et al. (2007) reported that FMO3 gene was located in a QTL region which associated with off-flavor in pigs. A nonsense mutation (R238X) of FMO3 gene was associated to underlie the fishy off-flavor in cow milk (Honkatukia et al. 2005). In chickens, a nonsynonymous mutation in the chicken $\mathrm{FMO} 3$ gene (T329S) has been investigated to be associated with elevated levels of TMA and fishy taint in the chicken egg yolk. However, no study has investigated the association study of these gene with regard to carcass and meat quality in duck. Notebly, functional and positional studies have suggested that these genes could be important candidate genes for carcass and meat quality. Therefore, the aim of this research was to study $\mathrm{FMO} 3$ gene through association analysis to prove its candidacy for carcass and meat quality traits in ducks.

\section{Materials and Methods}

\section{Animal and Phenotypes}

Seventy Six Indonesian Cihateup ducks were used in this study. The ducks were reared under the same feeding conditions until they were 12 weeks old and had approximately $1.6 \mathrm{~kg}$ of slaughter weight per duck. The carcass and meat quality data were collected according to the guidelines of the Indonesian performance test with the number $13-2016$ IPB.

\section{Carcass and Meat Quality Analysis}

The carcass traits included carcass weight $(\mathrm{CW})$, head weight $(\mathrm{HW})$, wing weight (WW), neck weight (NW), breast muscle weight (BMW), leg muscle weight (LMW) were measured after slaughter. Carcass yield was calculated by dividing carcass weight (flesh plus bones) by live weight (by removing head, viscera and foot weights). Meat cut ratio of 5 five parts viz. wings, back, neck, breast and legs, was calculated by dividing it with live weight, and then ratio of each part was calculated. The breasts were placed in plastic bags and refrigerated $\left(4^{\circ} \mathrm{C}\right.$ to $\left.6^{\circ} \mathrm{C}\right)$. At the laboratory, the samples were frozen at $-18^{\circ} \mathrm{C}$ until they were analyzed.

Meat quality traits analyzed in this study covered drip loss, cooking loss, $\mathrm{pH}$. Conductivity and $\mathrm{pH}$-values were measured using Star-series equipment (Rudolf Matthaeus Company, Germany) in breast meats. Drip loss was scored based on a bag-method with a sizestandardized sample from breast meats collected at $24 \mathrm{~h}$ p.m. that was weighed, suspended in a plastic bag, held at $4^{\circ} \mathrm{C}$ for $48 \mathrm{~h}$, and thereafter re-weighed (Kayan et al. 2013). To determine cooking loss, a breast meats cube was taken from the muscle, weighed, placed in a polyethylene bag and incubated in water at $75^{\circ} \mathrm{C}$ for $50 \mathrm{~min}$. The bag was then immersed in flowing water at room temperature for $30 \mathrm{~min}$ and the solid portion. The $\mathrm{pH}$ values of breast meats were measured $6 \mathrm{~h}$ post slaughter using a pH meter (Model 340, Mettler-Toledo, Greifensee, Switzerland). Briefly, $1 \mathrm{~g}$ of breast meat was cut into small pieces and homogenized with $9 \mathrm{~mL}$ of distilled water for 1 min in an Ultra-Turrax (Model No. T25, Janke and Kunkel, Staufen, Germany). Each sample was measured in triplicate and the mean values were used. Meat colour parameters (L*, 
lightness; $a^{*}$, redness; and b*, yellowness) were measured using a photoelectric spectrocolorimeter (CR-300, Minolta Camera Co.)

The meat samples were determined for level of pH using method of Van Lack et al.(2000). Cooking loss was measured refering to Bouton et al. (1971) method. Determination of drip loss was conducted by using Hamm (1972) method. While TMA analaysis were according to AOAC (2005). Measurements of TBARS were done using procedure of Sorensen and Jogersen (1996).

\section{DNA extraction, PCR reaction analysis of SNP}

Single nucleotide polymorphism described in Wang et al.(2013) (SNP) in the duck FMO3 gene was genotyped in the Cihateup population. For PCR amplification, the primer was designed from the duck $\mathrm{FMO}$ genomic sequence using the Primer3 tool (Rozen and Skaletsky, 2000) (Table 2). For genotyping, genomic DNA was isolated from the breast muscle (BM) tissue of the Indonesian Cihateup ducks according to the standard phenol-chloroform method (Gunawan et al. 2011). In silico analysis of the genomic sequence, performed by comparing several sequences from a publicly available database (NCBI), revealed the possible targets for PCR amplification. A working solution with a final concentration of $50 \mathrm{ng} / \mu \mathrm{l}$ was prepared and stored at $4{ }^{\circ} \mathrm{C}$ for further analysis. Polymerase chain reactions (PCRs) were performed in a 20 $\mu \mathrm{l}$ volume containing $2 \mu \mathrm{l}$ of genomic DNA, $1 \times$ PCR buffer (with $1.5 \mathrm{mM} \mathrm{MgCl}_{2}$ ), $0.25 \mathrm{mM}$ of dNTPs, $5 \mathrm{pM}$ of each primer and $0.1 \mathrm{U}$ of Taq DNA polymerase (GeneCraft). The genotyping of the Indonesian Cihateup duck population was performed by the PCR-RFLP method. The PCR product was analyzed using $1.5 \%$ agarose gel (Fischer Scientific Ltd.) and digested by using the restriction enzyme AlwNIfor FMO3 (New England Biolabs). After digestion, PCR-RFLP products were resolved on a $3 \%$ agarose gel. The fragments were visualized under ultraviolet light, and the sizes and number of the fragments were analyzed using molecular analyst software (Bio-Rad). PCR-RFLP patterns for FMO3 alleles were as follows: genotype AA resulted in two fragments (144 and $96 \mathrm{bp}$ ) while genotype $\mathrm{GG}$ resulted in one fragment (240 bp). The detailsof the PCR RFLP paattern, Genbank, accesion numbers and primer sequences used in this study was descibed according to Anggraeni et al. (2017).

\section{Statistical analysis}

Genotype and allele were and the Hardy weinberg equilibrium of the SNP was performed by the Chi square test using SAS. The association analysis between genotype of $\mathrm{FMO} 3$ with carcass and meat quality were performed using the generalized linear model (PROC GLM) of SAS (version 9.2 SAS Inst Inc., Cary, USA) was used. The model was as follows:

$Y i k l=\mu+$ genotypei+ eik

Yikl is the carcass and meat quality; $\mu$ is the overall mean; genotypei is the fixed effect of the $\mathrm{i}$-th genotype ( $\mathrm{i}=1$ and 2 ); which is the combination of location and penning (group, individual); and eik is the residual error. Leastsquares mean values for the loci genotypes were compared by t-tests, and $\mathrm{p}$-values were adjusted by the Tukey-Kramer correction (Cinaret al. 2012 ;Kayan et al. 2011).

\section{Results and Discussions}

\section{Phenotype of carcass and meat quality}

Descriptive parameters for carcass and meat quality traits data are given in Table 1 . For the studied population, the mean age was 12 weeks. Mean live weight (LW) of the ducks was $1472.73 \mathrm{~g}$. The average Carcass weight (CW), breast weight (BW), wing weight (WW) and leg weight (LMW) were 938.28 $\pm 116.07,238.72 \pm$ $51.51, \quad 132.42 \pm 12.97$ and $216.37 \pm 28.29$, respectively (Table 1 ). This result is lower that most previous duck carcass measurment in the literature. Gan et al. (2015) obtained CW and LW in Cherry Valley duck and Liancheng white 
were $1775.39 \mathrm{~g}$ and $1620.90 \mathrm{~g}$. Zhang et al. (2013) reported CW at 8 weeks in Peking duck was $2737 \mathrm{~g}$. Differences found among result are probably due to breed differences, selection pressure within population, sample size and environmental effect (Abdullah \&Olutogun, 2006).

The drip loss, cooking loss, $\mathrm{pH}$, redness and lightness and color of beast meat from Cihateup ducks are presented in Table 2. The average drip loss (DL), cooking loss $(C L), p H$, lightness $\left(L^{*}\right)$, redness $\left(a^{*}\right)$ and yellowness $\left(b^{*}\right)$ were $29.64 \pm 1.83 \%, 43.43 \pm 2.95 \%, 5.47 \pm 0.14$, $39.03 \pm 1.46,18.92 \pm 1.44$ and $3.19 \pm 0.58$ respectively (Table 2 ). We found that neither slaughter age nor slaughter weight affected the carcass and meat quality traits in the studied population. This result was in agreement which reported by Gan et al. (2015) that have measured meat quality in chinese duck crossbreed. Gan et al. (2015) revealed $\mathrm{pH}, \mathrm{L}^{*}$, $a^{*}$ and $b^{*}$ were 5,$4 ; 35,29 ; 18,11$ and 4,23 respectively.

It is necessary to characterize more precise carcass and meat quality standards for native breeds, including Indonesian Cihateup duck breed, to ensure their expanding consumption. The cooking loss of breast meat in this study was $43.43 \%$, which showed higher compare to commercial meat-type ducks, Cherry Valley. Qiao et al. (2017) reported cooking loos in Cherry Valley was range $34.5 \%$ to $35.6 \%$. Higher cooking loss in duck meat despite a higher proportion of oxidative fiber may be related to water holding capacity of duck (Ali et al. 2007).

Table 1.The average Carcass weight, breast, wing and leg weight

\begin{tabular}{|c|c|c|c|}
\hline Component of carcass & Means \pm STD & Min & Max \\
\hline Live weight (g) & $1472.73 \pm 120.17$ & 1224 & 1775 \\
\hline Head weight (g) & $84.22 \pm 8.18$ & 70 & 102 \\
\hline Neck weight (g) & $81.83 \pm 10.26$ & 60 & 100 \\
\hline Shank weight (g) & $48.08 \pm 8.10$ & 36 & 93 \\
\hline Carcass weight (g) & $938.28 \pm 116.07$ & 709 & 1270 \\
\hline Carcass percentage (\%) & $63.64 \pm 4.90$ & 54.16 & 74.94 \\
\hline Breast weight (g) & $238.72 \pm 51.51$ & 160 & 390 \\
\hline Breast percentage (\%) & $16.17 \pm 2.98$ & 9.26 & 24.90 \\
\hline Wing weight (g) & $132.42 \pm 12.97$ & 110 & 178 \\
\hline Breast muscle (g) & $197.33 \pm 48.25$ & 125 & 347 \\
\hline Leg weight (g) & $216.37 \pm 28.29$ & 169 & 272 \\
\hline Leg muscle (g) & $179.55 \pm 25.74$ & 128 & 233 \\
\hline
\end{tabular}

Table2. Traits and Quality Meat Duck

\begin{tabular}{llll}
\hline Traits & Means \pm STD & Min & Max \\
\hline $\mathrm{L}^{*}$ & $39.03 \pm 1.46$ & 35.23 & 40.86 \\
$\mathrm{a}^{*}$ & $18.92 \pm 1.44$ & 16.24 & 21.94 \\
$\mathrm{~b}^{*}$ & $3.19 \pm 0.58$ & 2.15 & 4.6 \\
$\mathrm{pH}$ & $5.47 \pm 0.14$ & 5.21 & 5.87 \\
Cooking Loss & $43.43 \pm 2.95$ & 38.12 & 50.27 \\
Drip Loss & $29.64 \pm 1.83$ & 26.21 & 33.43 \\
\hline
\end{tabular}

$L^{*}=$ Lighntess; $a^{*}=$ Redness; $b^{*}=$ Yellowness 


\section{Polymorphism Study of FMO3 gene}

The SNP of FMO3 at g.849A $>\mathrm{G}$ was confirmed by PCR-RFLP. Figure 1. depicts results of FMO3 gene amplication of PCR method. Animals of this population were genotyped at g.849A $>$ G in exon 1, which was the SNP segregating within Cihateup populations. In this study, two genotypes $A G$ and $G G$ were found with SNPs at g.849A>G in Cihateup population. The calculated genotype and allele frequencies of the $\mathrm{FMO}_{3}$ gene in the duck population are shown in Table 3. The homozygote GG was more frequent, and the heterozygote $A G$ was rare in our population. The chi-square test showed that the locus of FMO3 was in HardyWeinberg equilibrium in this Indonesian Cihateup duck population (Table 3 ). It is important to note that there is low allele frequency $(0.06 \%)$ for A on FMO3 (Table 3 ).

The genotype segregated into 2 genotypes, we convinced that these associations as reliable. This SNP characterized by PCR-RFLP method were in agreement with previous reports (Kramer et al. 2003; Malek and Lamont 2003; Tohidi et al. 2012). Results of amplification of FMO3 gene using PCR-RFLP method is presented in Figure 2.

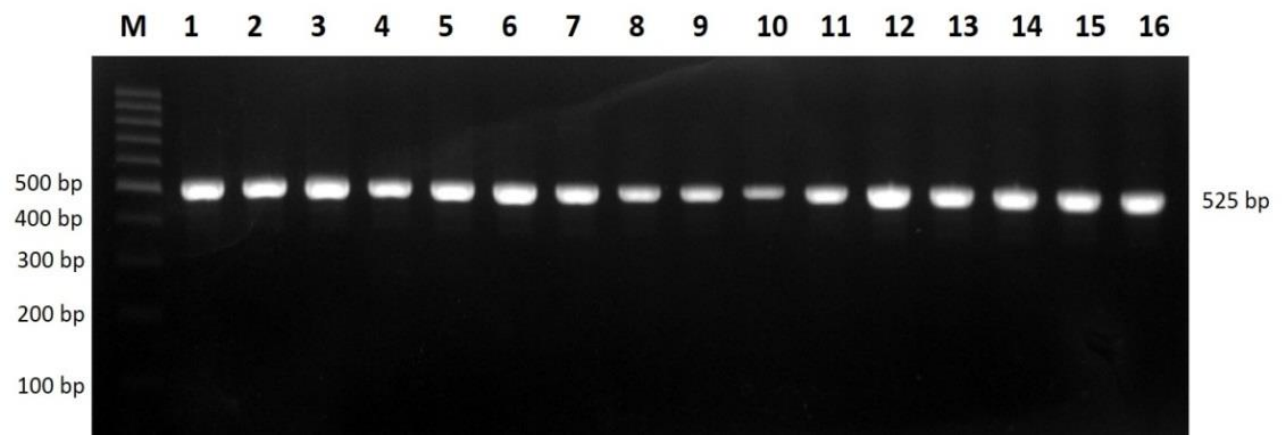

Figure 1. Amplification of FMO3 gene with the PCR method.

Table 3. Genotype, allele frequencies, and the chi-square test of FMO3 using RFLP

\begin{tabular}{|c|c|c|c|c|c|c|c|c|c|}
\hline \multirow{2}{*}{ Sample } & \multirow{2}{*}{$\mathrm{N}$} & \multicolumn{3}{|c|}{ Genotype frequency } & \multicolumn{4}{|c|}{ Allele frequency } & \multirow{2}{*}{$\chi^{2}$} \\
\hline & & $A A$ & $A G$ & GG & $A$ & G & $\mathrm{He}$ & Ho & \\
\hline Cihateup & 60 & 0.000 & $0.12(7)$ & $0.88(51)$ & 0.06 & 0.94 & 0.10 & 0.15 & 0.22 \\
\hline
\end{tabular}

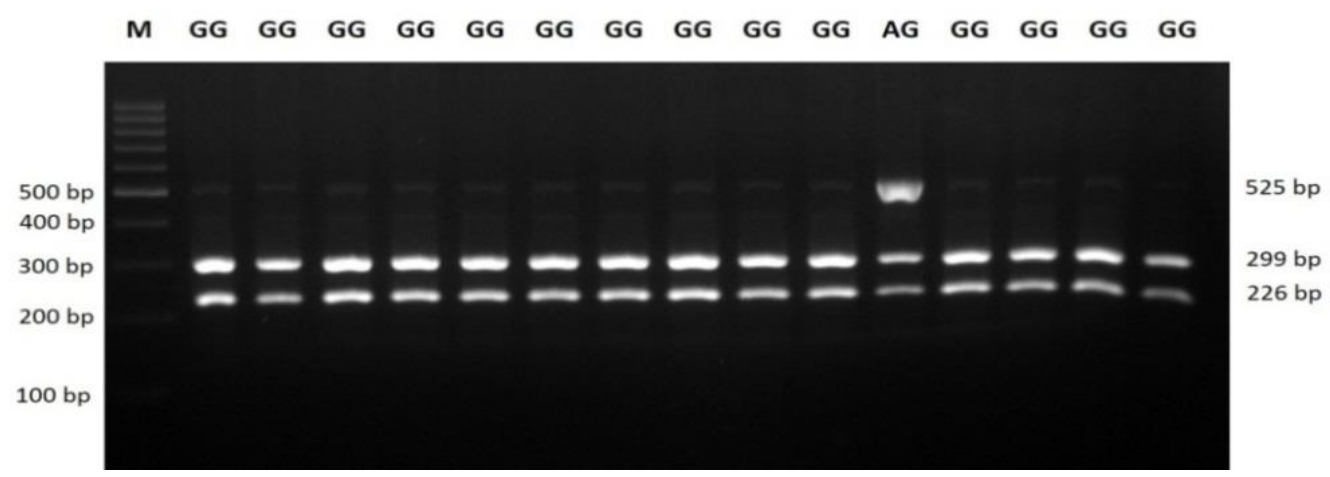

Figure 2. Results of FMO3 gene amplification using PCR-RFLP method. 
Cihateup ducks populations were polymorphic with two alleles found ( $A$ and $G$ ). Nei and Kumar (2000) and Allendroftet et al. (2013) mentioned that populations may be classified as polymorphic if there are more than one allele at the locus and if the most common allele frequencies are less than 0.99. The $\chi^{2}$ analysis showed that Cihateup duck populations were deviated/in from Hardy-Weinberg equilibrium. Allendroft et al. (2013) explained that $\chi^{2}$ is in Hardy-Weinberg equilibrium if the genetic variation, allele and genotype frequencies in a population remain constant from one generation to the next in the absence of disturbing factors

\section{Association of FMO3 polymorphisms with carcass quality}

In the present study, FMOg.849A SNP was significantly associated with carcass traits including live weight (LW), carcass weight (CW), carcass percentage (\%), breast weight (BW), breast percentage (\%) and breast muscle (g) (Table 4). The AG genotype exhibited the highest values for the carcass traits, which were significantly higher than the GG genotype for $\mathrm{LW}, \mathrm{CW}$, and were significantly higher than the $G G$ and $G A$ genotypes for BW $(P<0.05)$.
Considering the effect of the FMO3 gene, we were chosen to perform an association study with meat and carcass quality traits according to its physiological roles and chromosomal position that linked to several QTL for meat quality traits in in duck. The FMO family of enzymes converts lipophilic compounds into more polar metabolites and decreases the activity of these compounds (Cashman, 2005).The SNP of FMO3 was reported previously in pig, birds and mammals, but association study were performed with fishy and boar taint (Gunawan et al. 2013; Glenn et al. 2007; Honkatukia et al. 2005; Lunden et al. 2002). In pigs, the FMO3 gene was located in a QTL region correlated with off-flavor, which identified of an association between the $\mathrm{FMO} 3$ gene and off-flavor in pigs. Gunawan et al. (2013) reported association other FMOs family of FMO5 with androstenone levels (boar taint). A nonsynonymous mutation in the chicken FMO3 gene (T329S) was reported to be associated with elevated levels of TMA and fishy taint in the chicken egg yolk. In cattle, a nonsense mutation (R238X) in the cattle FMO3 gene was revealed to underlie fishy off-flavor in cow milk.

Table 4. Association of FMO3 polymorphisms with carcass traits

\begin{tabular}{lrr}
\hline Component of carcass & \multicolumn{2}{c}{ Genotype } \\
\cline { 2 - 3 } & \multicolumn{3}{c}{ AG (7) } & AA (69) \\
\hline Live weight $(\mathrm{g})$ & $1575 \pm 59.65 \mathrm{a}$ & $1459.23 \pm 119.92 \mathrm{~b}$ \\
Head weight $(\mathrm{g})$ & $84.14 \pm 7.08$ & $84.23 \pm 8.38$ \\
Neck weight $(\mathrm{g})$ & $86.57 \pm 8.87$ & $81.21 \pm 10.34$ \\
Shank weight $(\mathrm{g})$ & $48.14 \pm 6.20$ & $48.08 \pm 8.37$ \\
Carcass weight $(\mathrm{g})$ & $1076.71 \pm 102.71 \mathrm{a}$ & $920.00 \pm 105.59 \mathrm{~b}$ \\
Carcass percentage (\%) & $68.26 \pm 4.32 \mathrm{a}$ & $63.03 \pm 4.67 \mathrm{~b}$ \\
Breast weight $(\mathrm{g})$ & $309.86 \pm 55.34 \mathrm{a}$ & $229.32 \pm 43.42 \mathrm{~b}$ \\
Breast percentage (\%) & $20.06 \pm 3.36 \mathrm{a}$ & $15.95 \pm 2.42 \mathrm{~b}$ \\
Wing weight $(\mathrm{g})$ & $140.71 \pm 8.62$ & $131.32 \pm 13.11$ \\
Breast muscle $(\mathrm{g})$ & $253.86 \pm 34.40 \mathrm{a}$ & $189.87 \pm 44.92 \mathrm{~b}$ \\
Leg weight $(\mathrm{g})$ & $229.14 \pm 33.67$ & $214.68 \pm 27.43$ \\
Leg muscle $(\mathrm{g})$ & $182.43 \pm 28.75$ & $179.17 \pm 25.59$ \\
\hline
\end{tabular}


Carcass and meat quality could be affected by LW (Galián et al. 2009; Choi et al. 2013), which is what we found in SNP g.849A $>$ G. The quality of fresh meat can be controlled by the modification of muscle fiber characteristics, and that the IMF content is positively correlated with the amount of red muscle fiber but is negatively correlated with the amount of white muscle fiber (Joo et al. 2013). In this study, The GG genotype was associated with increased BM than AG genotype. It could be mentioned that there was differences between the BM, which may indicate that muscle fiber characteristics is also an important aspect of duck meat quality. Estimation of aerobic capacity data have recommended that the BM and LM are mainly composed of fast and slow muscle fibers, respectively, in poultry (Turner and Butler, 1988).

\section{Association of $\mathrm{FMO3}$ polymorphisms with meat quality}

Association analysis of the g.849A >G SNP with meat quality revealed significant $(P<0.01)$ associations with $\mathrm{pH}$, drip loss, ligtness $\left(\mathrm{L}^{*}\right)$ redness $\left(a^{*}\right)$, TBARS and TMA. Compared to the GG phenotype $(P<0.05)$, the genotype $A G$ exhibited greater compositions of $\mathrm{pH}$, redness $\left(a^{*}\right)$, TBARS and TMA but not drip loss and ligtness $\left(L^{*}\right)$ (Table 5$)$.

FMO3 is major member of the FMO family and is primarily present in the adult human liver, where it plays an important role in the metabolism of xenobiotic-containing TMA (Wang et al. 2013). TMA is the main compound causing the human metabolic disorder TMAU, the fishy off-flavor in dairy milk and the fishy taint in chicken eggs. The genotype AG exhibited greater compositions of $\mathrm{pH}$, redness (a*), TBARS and TMA but not drip loss and ligtness $\left(L^{*}\right)$. The colour redness $\left(a^{*}\right)$ differences found in this study might be explained by differences in $\mathrm{Fe}$ or haematin content. Furthermore, protein matrix microstructure, the chemical states of myoglobin, or oxygen diffusion might be other influencing factor that responsible for controling the colour in meat quality (Sañudo et al. 1997; Swatland, 2012), The lightness ( L*) $^{*}$ of meat quality was different between $A G$ and GG genotype (Table 5).The discrepancy between this genotype, could be explained by differences in duck muscle composition or structure that affect light scattering, oxygen diffusion and/or myoglobin changes (Mateo et al. 2017). The TBARS of meat quality was different between AG and GG genotype (Table 5). These differences could be propertized to the concentration of muscle compounds that affect lipid oxidation, that is, released Fe from myoglobin, PUFA or tocopherols (Min and Ahn, 2005). TBARS is also considered as the acceptable oxidation level of raw meat quality before cooking (Campo et al. 2006). The higher expression of FMO3 in ducks with high carcass and meat quality (LW, CW, $\mathrm{pH}$, redness (a*), TBARS and TMA) suggested that FMO3 might be involved in regulating in carcass and meat quality traits.

Table5. Association of FMO3 polymorphisms with meat quality

\begin{tabular}{lrr}
\hline Traits & AG (7) & AA (69) \\
\hline L* $^{*}$ & $38.20 \pm 1.75$ & $39.14 \pm 1.41$ \\
a* & $20.90 \pm 0.95 \mathrm{a}$ & $18.66 \pm 1.29 \mathrm{~b}$ \\
$\mathrm{~b}^{*}$ & $3.31 \pm 0.55$ & $3.18 \pm 0.59$ \\
pH & $5.83 \pm 0.10 \mathrm{a}$ & $5.30 \pm 0.23 \mathrm{~b}$ \\
Cooking Loss & $46.05 \pm 3.51 \mathrm{a}$ & $43.08 \pm 2.72 \mathrm{~b}$ \\
Drip Loss & $28.60 \pm 1.54$ & $29.78 \pm 1.84$ \\
TBARS & $1.36 \pm 0.24 \mathrm{a}$ & $1.09 \pm 0.22 \mathrm{~b}$ \\
TMA & $8.53 \pm 0.55 \mathrm{a}$ & $7.36 \pm 1.09 \mathrm{~b}$ \\
\hline
\end{tabular}

$L^{*}=$ Lighntess; $a^{*}=$ Redness; $b=$ Yellowness 


\section{Conclusions}

This study demonstrated that polymorphisms in $\mathrm{FMO} 3$ at g.849A $>\mathrm{G}$ might contribute to the selection of carcass and meat quality traits in Indonesian Cihateup ducks. In general, the genotype AG was higher in carcass and meat quality with the characteristic (high LW, CW, pH, redness (a*), TBARS and TMA) in ducks. These results have implications for genomic selection because the $\mathrm{FMO}$ gene is associated with carcass and meat quality traits in ducks. However, the sample size used to determine the association was small, so validation in a larger sample size is necessary

\section{Acknowledgments}

The authors gratefully acknowledge the Directorate General of Higher Education, Ministry of Education and Culture of The Republic of Indonesia for the financial support through a Hibah Doktor No. 105/SP2H/DRPM/II/2016.

\section{References}

Abdullah AR and OOlutogun. 2006. Estimates of genetic and phenotypic parameters for preweaning growth traits of N'Dama (Bos Taurus) calves in the humid tropics of Nigeria. Livest Res Rur Develop. http://www.cipav.org.co /lrrd/Irrd18/8/ab du18120.htm [1 December 2006].

Ali MD, Shawkat, GH Kang, HS Yang, JY Jeong, YH Hwang, GB Park and ST Joo. 2017. A Comparison of Meat Characteristics between Duck and Chicken Breast. Asian-Aust J Anim Sci. 6: 10021006.

Allendorf FW, G Luikar and SN Aitken. 2013. Conservation and the genetics of population. $2^{\text {nd }}$ Ed. Wiley-Blackwell Publishing. UK. 303 pages.

Anggraeni, A Gunawan, Rukmiasih, T Suryati and C Sumantri. 2017. Association and expression analysis of the duck FMO3 gene in relation to fatty acid composition. Int. J. Poult. Sci. Accepted. Doi:10.3923/ijps.2017

[AOAC] Association Official Analitycal Chemistry. 2005. Official Methods of analysis. Edisi ke-18. Maryland (US): AOAC Inc.
Boukha A, V Bonfatti, A Cecchinato, A Albera, L Galo, P Camier and G Britantte. 2011. Genetic parameters of carcass and meat quality traits of double muscled Piedmontese cattle. Meat Sci. 89: 84-90.

Campo MM, GR Nute, SI Hughes, M Enser, JD Wood and RI Richardson. 2006. Flavor perception of oxidation in beef. Meat Sci. 72: 303-311.

Cashman JR. 2005. Some distinctions between flavincontaining and cytochrome P450 monooxygenases. Biochem Biophys Res Commun. 338: 599-604.

Choi YM, KW Nam, JH Choe, YC Ryu, MP Wick, K Lee and BC Kim. 2013. Growth, fiber type, and meat quality characteristics in large white pig with different live weight. Livest Sci. 155:123-129.

Cinar, MU,A Kayan,MJ Uddin, E Jonas,,D Tesfaye, C Phatsara, S Ponsuksili, K Wimmers, E Tholen, C Looft, H Jüngst, and K Schellander.2012. Association and expression quantitative trait loci (eQTL) analysis of porcine AMBP, GC and PPP1R3B genes with meat quality traits. Mol Biol Rep. 39: 4809-4821.

Galian M, A Poto and B Peinado. 2009. Carcass and meat quality traits of the Chato Murciano pig slaughtered at different weights. Livest Sci. 124: 314-320.

Gan W, Q Song, NN Zhang, XP Xiong, DMC Wang and $\mathrm{N}$ Li. 2015. Association between FTO polymorhism in exon 3 with carcass and meat quality traits in crossbreed ducks. Genet Mol Res. 14: 6699-6714.

Gleen KL, AM Ramos and Rothshild. 2007. Analysis of FMO genes and off flavor in pork. J Anim Breed Genet. ISSN. 0931-2668.

Gunawan A, K Kaewmala, MJ Uddin, MU Cinar, D Tesfaye, C Phatsara, E Tholen, C Looft and K Schellander. 2011. Association study and expression analysis of porcine ESR1 as a candidate gene for boar fertility and sperm quality. Anim Reprod Sci. 128: 11-21.

Gunawan A, S Sahadevan, C Neuhoff , C Große Brinkhaus, A Gad, L Frieden, D Tedfaye, E Tholen, C Looft, MJ Uddin, K Schellander and MU Ulas. 2013. RNA Deep Sequencing Reveals Novel Candidate Genes and Polymorphisms in Boar Testis and Liver Tissues with Divergent Androstenone Levels. PLoS One. 8(5): e63259.

Honkatukia M, K Reese, R Preisinger, MT uiskulaHaavisto, S Weigend, J Roito, A Maki-Tanila and J Vilkki. 2005. Fishy taint in chicken eggs is associated with a substitution within a conserved motif of the FMO3 gene. Genomics. 86: 225-232.

Joo ST, GD Kim, YH Hwang and YC Ryu. 2013. Control of fresh meat quality through 
manipulation of muscle fiber characteristics. Meat Sci. 95: 828-836.

Kayan A, MU Cinar, MJ Uddin, C Phatsara, K Wimmers, S Ponsuksili, D Tesfaye, CLooft,HJ uengst, E Tholen and K Schellander. 2011. Polymorphism and expression of the porcine Tenascin C gene associated with meat and carcass quality. Meat Sci. 89: 76-83.

Kramer J, M Malek and SJ Lamont. 2003. Association of twelve candidate gene polymorphisms and response to challenge with Salmonella enteritidis in poultry. Anim Genet. 34: 339-348.

Lee HJ, DD Jayasena, SH Kim, HJ Kim, KN Heo, JE Song and C Jo. 2015. Comparison of bioactive compounds and quality traits of breast meat from korean native ducks and commercial ducks. Korean J Food Sci Anim Res. 35: 114-120.

Lunden A, M Stefan, G Victoria and A Left. 2002. A nonsense mutation in the FMO3 gene underlies fishy off-flavor in cow milk. Genom Res Dec. 12: 1885-1888.

Malek M and SJ Lamont. 2003. Association of INOS, TRAIL, TGF- $\beta 2$, TGF- $\beta 3$, and IgL genes with response to Salmonella enteritidis in poultry. Genet Sel Evol. 35: S99-S111.

MalekM, JR Hasenstein and SJ Lamont. 2004. Analysis of chicken TLR4, CD28, MIF, MD-2, and LITAF genes in a Salmonella enteritidis resource population. Poult Sci. 83: 544-549.

Mateo, $\mathrm{Cl}$, DE Carballo, N Gutiérrez-Méndez, JJ Arranz and B Gutiérrez-Gil . 2017. Carcass and meat quality characteristics of churta and assafsuckly lambs. Animal. 1-9.

Min B and DU Ahn. 2005. Mechanism of Lipid Peroxidation in Meat and Meat Products -A Review. Food Sci Biotechnol. 14: 152-163.

Mo F, J Zheng, P Wang, L Lian, G Yi, G Xu and N Yang. 2013. Quail FMO3 gene cloning tissue expassion profiling polymorphism detection and association analysis with fishy taint in eggs. Plos ONE 8: E 81416.

Muhsinin M, N Ulupi, A Gunawan, IWT Wibawan and C Sumantri. 2016. Association of NRAMP1 polymorphisms with immune traits in Indonesian native chickens. Int J Poult Sci. 15: 401-406.

Nei M and S Kumar. 2000. Molecular Evolution and Phylogenetics. Oxford University Press. New York. 333 pages.

Qiao, YJ Huang, Y Chen, H Chen, L Zhao, M Huang and G Zhou. 2017. Meat Quality, fatty acid composition and Sensory evaluation. Anim Sci J. 88: 156-165.

Rozen S and H Skaletsky. 2000. Primer3 on the WWW for general users and for biologist programmers. Methods Mol Biol. 132: 365-86.
Sambrook J and D Russell. 2001. Molecular Cloning: A Laboratory Manual. $3^{\text {rd }}$ Ed. Cold Spring Harbor Laboratory Press. USA. 2100 pages.

Sañudo C, MM Campo, IM Sierra, GA María, JL Olleta and $P$ Santolaria. 1997. Breed effect on carcass and meat quality of suckling lambs. Meat Sci. 46:357-365.

Sanz M, CJ Lopez-Bote, D Menoyo and JM Bautist. 2000. Abdominal fat deposition and fatty acid synthesis are lower and $\beta$-oxidation is higher in broiler chickens fed diets containing unsaturated rather than saturated fat. J Nutr. 130: 30343037.

Sorensen G, Jogersen S. 1996. A critical examination of some experimental variables in the 2thiobarbituric acid (TBA) test for lipid oxidation in meat products. Z Lebensem Unters Forsch. 202:205-210.

Swatland HJ. 2012. Optical properties of meat at North Dakota State University. In: Proceedings of the 65th Reciprocal Meat Conference. Fargo, June 17 2012. Pp. 1-7

Tohidi R, I Idris, JM Panandam and MH Bejo. 2012. The effects of polymorphisms in IL-2, IFN- $\gamma$, TGF$\beta 2$, IgL, TLR-4, MD-2, and iNOS genes on resistance to Salmonella Enteritidis in indigenous chickens. Avian Pathol. 41(6): 605-612.

Turner and Butler. 1988. The aerotic capacity of locomotory muscle in the tufted duck aythya fuligula. J Exp Biol. 135.445-460

van der Steen HAM, GFW Prall and GS Plastow. 2005. Application of genomicsto the pork industry. J Anim Sci. 83: E1-E8.

Van laack RL, Stevens SG, Stadler KJ. 2000. The Influence $\mathrm{pH}$ and intramuscular fat content on pork tenderness and tenderization. J Anim Poult Sci. 79: 392-397.

Wang $\mathrm{P}$, J Zheng, L Qu, L Lian, G Xu and $\mathrm{N}$ Yang. 2013. Molecular cloning, sequence characterization, SNP detection, and tissue expression analysis of duck FMO3 gene. Mol Cell Biochem. 379: 141-151.

Wang Y, X Cui, G Tai, J Ge, N Li, F Chen, F Yu and Z Liu. 2009. A Critical Role of Activin $A$ in Maturation of Mouse Peritoneal Macrophages in vitro and in vivo. Cell Mol Immunol. 6: 387-392.

Zhang HL, HJ Fan, XL Liu, Y Wu and SS Hou. 2013. Molecular cloning of the perilipin gene and its association with carcass and fat traits in chinese duck. Genet Mol Res. 12: 1582-1592.

Zhou H, H Li and SJ Lamont. 2002. Genetic markers associated with antibody response kinetics in adult chickens. Poult Sci. 82: 699-708. 